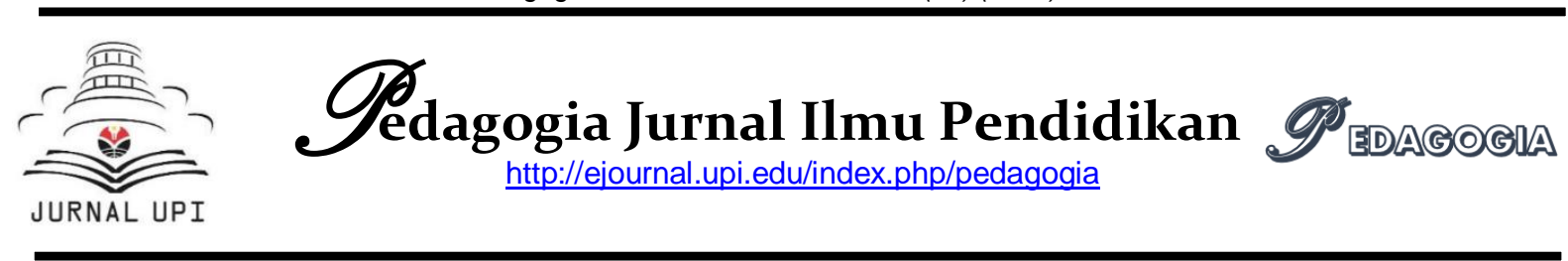

\title{
Persepsi Mahasiswa Terhadap Mobile learning Berbasis Android
}

\author{
Sulia Ningsih \\ Program Studi Teknologi Pendidikan \\ FKIP - Universitas Baturaja \\ sulia2833@gmail.com
}

\begin{abstract}
This research based on the use of android is inseparable from human life, including students. Android primrer become a necessity as well as human needs will eat, clothing and shelter. The research aims to review the perception of a student of mobile learning based on android; in course of study educational technology FKIP Baturaja University who viewed from: 1 ) Student understanding of mobile learning an android; 2 ) Benefits android in learning student; 3 ) Readiness student in the use of mobile learning based on android. The research is descriptive quantitative research.The research are students course of study technology education academic year 2019 / 2018. The survey an instrument used that have been analyzed using a technique descriptive analysis. This research result indicates 72,97 understand mobile learning based android, 75,67\% know mobile benefits learning based android and $81,08 \%$ said readiness as of mobile learning based android. The results of the analysis must provide an adequate decision lecturers to important to use mobile learning android based on learning in the study technology education.
\end{abstract}

Keywords: E-Learning, Mobile Learning, Android

\begin{tabular}{|c|}
\hline Article Info \\
\hline $\begin{array}{l}\text { Naskah Diterima: } \\
\text { 2019-03-11 }\end{array}$ \\
\hline $\begin{array}{l}\text { Naskah Direvisi: } \\
\text { 2019-04-04 }\end{array}$ \\
\hline $\begin{array}{l}\text { Naskah Disetujui: } \\
\text { 2019-04-26 }\end{array}$ \\
\hline
\end{tabular}

\begin{abstract}
A b s trak
Penelitian ini dilatarbelakangi penggunaan android yang tidak bisa dipisahkan dari kehidupan manusia, termasuk mahasiswa. Android menjadi kebutuhan primrer seperti halnya kebutuhan manusia akan makan, pakaian dan tempat tinggal. Penelitian bertujuan untuk mengetahui persepsi mahasiswa terhadap mobile learning berbasis android di Program Studi Teknologi Pendidikan FKIP Universitas Baturaja yang dilihat dari: 1) Pemahaman mahasiswa terhadap mobile learning berbasis android; 2) Manfaat android dalam pembelajaran mahasiswa; 3) Kesiapan mahasiswa dalam penggunaan mobile learning berbasis android. Penelitian ini merupakan penelitian deskriptif kuantitatif. Sampel penelitian adalah mahasiswa Program Studi Teknologi Pendidikan tahun akademik 2018/2019. Instrumen dalam penelitian ini menggunakan angket yang dianalisis menggunakan teknik analisis deskriptif. Hasil penelitian ini menunjukkan $72,97 \%$ memahami mobile learning berbasis android, 75,67\% mengetahui manfaat mobile learning berbasis android dan 81,08\% menyatakan kesiapan pada penggunaan mobile learning berbasis android. Hasil analisis tersebut memberikan informasi yang cukup penting pada keputusan dosen untuk menggunakan mobile learning berbasis android pada pembelajaran di Program Studi Teknologi Pendidikan.
\end{abstract}

Kata Kunci: E-Learning, Mobile Learning, Android 


\section{A. PENDAHULUAN}

Pesatnya perkembangan IPTEK di dunia membawa perubahan peradaban baru yang sangat pesat di berbagai bidang termasuk dalam bidang pendidikan dan pembelajaran. Lahirnya berbagai macam platform semakin memudahkan manusia untuk mencari informasi dan berkomunikasi. Semakin berkembangnya teknologi memberikan dampak positif untuk pendidikan Indonesia. Sebetulnya pendidikan di Indonesia sendiri telah banyak mengalami inovasi dari tahun ke tahun dalam bentuk sarana prasarana yang digunakan untuk memperlancar jalannya kegiatan belajar mengajar maupun keseluruhan sistem pendidikan. Tujuannya agar pendidikan menjadi lebih efektif, efisien dan menarik bagi peserta didik dan pendidik.

Teknologi pendidikan berupaya memanfaatkan aneka sumber belajar sehingga dapat memudahkan atau menfasilitasi seseorang untuk belajar dimana saja, kapan saja, dan oleh siapa saja. Dengan memanfaatkan teknologi seperti komputer, masalah belajar dan pembelajaran dapat dipecahkan dalam setiap aktivitas pendidikan. Komputer adalah mesin yang dirancang khusus untuk memanipulasi informasi yang diberi kode, serta merupakan mesin elektronik yang otomatis melakukan pekerjaan dan perhitungan sederhana dan rumit (Kusnandi \& Sutjipto, 2011).

Awalnya komputer berbentuk PC (Personal Computer) atau desktop menjadi alat utama pelaksanaan e-learning. Kelas virtual atau lebih dikenal dengan e-learning, merupakan salah satu bentuk pemanfaatan internet yang dapat meningkatkan peran peserta didik dalam proses pembelajaran. Berbagai layanan e-learning telah tersedia baik yang dikelola mandiri oleh institusi dengan menggunakan Learning Management System (LMS) maupun yang disediakan secara bebas oleh pihak ketiga. (Saifuddin, 2017).

Namun pembelajaran jarak jauh atau e-learning tidak hanya terbatas pada penggunaan komputer saja, dengan pemanfaatan komunikasi pada perangkat bergerak memungkinkan pengembangan fitur e-learning. Dengan menggunakan web mobile, aplikasi e-learning dapat diakses melalui mobile browser dengan menggunakan koneksi internet. (Belina \& Batubara, 2013). Mobile browser yang dimaksud disini adalah smartphone atau ponsel pintar. Teknologi internet menjadi sebuah kecendrungan baru yang memungkinkan pembelajaran dapat dilakukan secara mobile. Akses layanan internet saat ini tidak hanya terbatas pada komputer dan laptop, tetapi internet dapat diakses dari perangkat mobile ketika jaringan tersedia. Kombinasi teknologi telekomunikasi dan internet memungkinkan pengembangan sistem mobile learning (Thohari, Satoto, \& Martono, 2013).

Hal ini tentu saja didasari pada pengguna smartphone yang semakin luas dan hampir tersebar pada setiap aspek tingkatan umur. Salah satu produk teknologi yang sekarang banyak digunakan mampu menembus pasar dunia adalah smartphone. Jumlah smartphone yang digunakan disuluh dunia berjumlah sekita 1,7 milliar smartphone, sedangkan total penduduk dunia adalah 6 milliar (Higgins \& Shudong, 2012), hampir menyentuh angka $30 \%$ dari total penduduk dunia. Hal tersebut tentu saja menjadi potensi untuk meningkatkan kualitas pembelajaran berbasis khususnya pembelajaran berbasis mobile atau m-learning.

Potensi pengembangan aplikasi menambah banyaknya masyarakat yang menggunakan smartphone (Demidowich et al., 2012), hal tersebut berpotensi dapat digunakan untuk mendukung aktivitas 
pendidikan dan pembelajaran salah satunya adalah mobile learning (Chao, Parker \& Howcort, 2011). Penetrasi pengguna internet dan juga mobile didominasi oleh kalangan usia muda, sehingga pemanfaatan piranti mobile untuk kegiatan pembelajaran menjadi memungkinkan (Sulisworo, Jauhari, \& Firdausy, 2014).

Mahasiswa sebagai peserta didik merupakan kelompok masyarakat yang pada umumnya mengikuti tren perkembangan teknologi terbaru hal ini smartphone, baik konten maupun fungsinya yang selama ini masih didominasi oleh konten hiburan. Data yang diperoleh dari website gs.statcounter.com menunjukkan persentase penguna sistem operasi mobile Android di dunia selama satu tahun terakhir unggul dengan nilai 52,98\% per Juni 2014 dibandingkan sistem operasi lainnya. Isu inilah yang menjadikan smartphone menjadi pilihan terbaik dalam pengaplikasian mobile e-learning ini dikarenakan kehandalan smartphone yang hampir sama dengan komputer serta cara penggunaannya sudah lebih dikenal oleh masyarakat dibandingkan dengan komputer.

Program studi Teknologi Pendidikan merupakan salah satu program studi yang memiliki karakteristik dalam penggunaan dan pemanfaatan semua jenis media dalam menjalankan berbagai macam kegiatan pendidikan dan pembelajaran. Hal ini juga berlaku di Program Studi Teknologi Pendidikan FKIP Universitas Baturaja. Prodi Teknologi Pendidikan FKIP Universitas Baturaja dituntut untuk lebih peka terhadap perkembangan teknologi termasuk pembelajaran berbasis e-learning.

Program Studi Teknologi Pendidikan telah menggunakan model pembelajaran e-learning. Aplikasi Edmodo dan website adalah media berbasis ICT yang digunakan untuk menunjang aktivitas pembelajaran yang dilakukan oleh Dosen di lingkungan Program Studi Teknologi Pendidikan. Dalam upaya pengembangan model pedagogi dan mutu pembelajaran dengan penerapan e-learning lebih jauh, maka dalam hal ini akan diidentifikasi, dikaji, dan ditelaah lebih jauh mengenai persepsi mahasiswa mengenai mobile learning berbasis android.

Berangkat dari asumsi mengenai peluang inovasi dan variasi e-learning melalui pembelajaran mobile learning berbasis android, maka perlu untuk dikaji lebih dalam dengan melihat sejauh mana pengetahuan mahasiswa mengenai pemahaman, kesiapan dan fasilitas yang ada dalam mendukung pelaksanaan mobile learning berbasis android, sehingga dapat diketahui tindakan selanjutnya untuk melakukan pemanfaatan atau pengembangannya. Penelitian ini bertujuan untuk mengetahui persepsi mahasiswa Program Studi Teknologi Pendidikan Universitas Baturaja terhadap mobile learning berbasis android.

\section{B. TINJAUAN PUSTAKA \\ 1. E-learning}

E-learning atau electronic learning saat ini menjadi tren pada bidang pendidikan dan pembelajaran. Secara terminilogis, e-learning dapat dimaknai sebagai proses pembelajaran jarak jauh dengan menggabungkan prinsip-prinsip dalam proses pembelajaran dengan teknologi (Chandrawati, 2010). Selanjutnya (Michael, 2013) menjelaskan bahwa pembelajaran yang disusun dengan tujuan menggunakan sistem elektronik atau komputer sehingga mampu mendukung proses pembelajaran.

Lebih lanjut Rosenberg (2001) menjelaskan bahwa e-learning sebagai salah satu bentuk inovasi pada bidang pendidikan dan pembelajaran memilki 
karakteristik khusus, yaitu bersifat jaringan, yaitu memilkiki kemampuan memperbaiki secara cepat, menyimpan atau memunculkan kembali, mendistribusikan, dan sharing pembelajaran dan informasi.

Sedangkan pendapat lain mengenai karakteristik e-learning menurut Nursalam (2008) adalah sebagai berikut:

1. Memanfaatkan jasa teknologi elektronik.

2. Memanfaatkan keunggulan komputer

3. Self learning materials.

4. Jadwal pembelajaran, kurikulum, hasil kemajuan belajar, dan hal-hal yang berkaitan dengan administrasi pendidikan dapat dilihat setiap saat di komputer.

\section{Mobile learning}

Mobile learning adalah perpaduan atau kombinasi antara E-learning dan Mobile Computing yang dapat mengakses suatu aplikasi pembelajaran kapanpun (anytime) dan dimanapun (anywhere) (Thohari, Satoto, \& Martono, 2013). M-learning adalah bagian tujuan e-learning yang memberikan peluang yang lebih luas secara mobile dan kemampuan yang lebih pada siswa dalam pembelajaran. Dengan demikian m-learning dapat didefinisikan secara berbeda dengan e-learning terkait dengan mobilitas peserta didik sebagai pebelajar. Pembelajaran dapat terjadi ketika pebelajar mengambil keuntungan dari peluang-peluang belajar yang diberikan oleh teknologi mobile (Sulisworo, Jauhari, \& Firdausy, 2014).

Pertumbuhan ini ditunjang karena kelebihan handset berbasis Android yang memiliki kemampuan multitasking yang lebih baik, serta harga handset yang semakin terjangkau. Sistem operasi Android, dimana ponsel yang menggunakan O.S. Android memiliki beberapa kelebihan dibanding sistem lain, baik dari segi hardware maupun software yang diklaim open source (Prabowo, Setiawan, \& Prakoso, 2013). Android merupakan sebuah sistem operasi bergerak (mobile operating system) yang mirip dengan sistem oleh operasi Linux, namun telah dimodifikasi. (Matlubah, Anekawati, \& Ngadi, 2016).

\section{Android}

Android adalah sistem operasi yang untuk telepon seluler seperti telepon pintar dan komputer tablet. Android menyediakan platform terbuka bagi para pengembang untuk menciptakan aplikasi mereka sendiri untuk digunakan oleh bermacam peranti bergerak. Awalnya, Google Inc. membeli Android Inc., pendatang baru yang membuat peranti lunak untuk ponsel. Kemudian untuk mengembangkan Android, dibentuklah Open Handset Alliance, konsorsium dari 34 perusahaan peranti keras, peranti lunak, dan telekomunikasi, termasuk Google, HTC, Intel, Motorola, Qualcomm, T-Mobile, dan Nvidia. (Listyorini, 2013).

Lebih lanjut ia menjelaskan bahwa Android sebagai sistem operasi pada perangkat mobile atau smartphone memilki fitur-fitu, sebagai berikut :

a. Framework aplikasi, memungkinkan daur ulang dan penggantian komponen.

b. Browser terintegrasi berbasis engine Open Source WebKit yang juga digunakan di browser IPhone dan Nokia S60v3.

c. Rancangan handset. Platform disesuaikan dengan kebutuhan VGA (Video Graphics Adapter) yang lebih besar, library grafik 2D dan 3D yang berdasarkan pada spesifikasi OpenGL ES 1.0 serta layout smartphone yang tradisional.

d. Multi-touch. Android memiliki dukungan bawaan untuk multitouch yang tersedia pada handset terbaru seperti HTC Hero. 
e. Dukungan hardware tambahan. Android mendukung penggunaan kamera, layar sentuh, GPS (Global Positioning System), pengukur kecepatan, magnetometer, akselerasi 2D bit blits (dengan orientasi hardware, scaling, konversi format piksel) dan akselerasi grafis 3D.

\section{METODE PENELITIAN}

Penelitian ini merupakan penelitian kuantitatif deskriptif dengan teknik pengambilan datanya menggunakan angket. Penelitian diskriptif adalah penelitian mendiskripsikan hal-hal yang saat ini berlaku, sedangkan menurut jenis data dan cara pengolahannya yang angka dan dianalisis menggunakan uji statistik maka digolongkan dalam penelitian kuantitatif. Skor yang diperoleh kemudian dianalisis dengan menggunakan teknik statistik deskriptif yang dituangkan dalam bentuk presentase.

Penelitian ini mulai dilaksanakan pada bulan Juli sampai dengan September 2018 di Program Studi Teknologi Pendidikan Universitas Baturaja. Variabel penelitian ini adalah persepsi mahasiswa terhadap mobile learning berbasis android. Persepsi mahasiswa yang dimaksudkan dalam penelitian ini adalah pandangan mahasiwa di dalam menginterpretasi, menerjemahkan, atau memahami e-learning berbasis android sehingga berimplikasi terhadap proses pencapaian dari tujuan pembelajaran.

Populasi penelitian ini adalah mahasiswa Program Studi Teknologi Pendidikan yang masih aktif menempuh mata kuliah pada tahun Akademik 2018/2018 berjumlah 125 orang. Sampel penelitian ini diambil 30\% dari jumlah populasi yaitu 37orang mahasiswa.

Pada penelitian ini, instrumen penelitian yang digunakan berupa angket tertutup berisi daftar pertanyaan dengan berbagai alternatif jawaban yang didasarkan pada skala likert. Data hasil penelitian mendeskripsikan tentang 1) Pemahaman mahasiswa terhadap mobile learning berbasis android; 2) Manfaat android dalam pembelajaran mahasiswa; 3) Kesiapan mahasiswa dalam penggunaan mobile learning berbasis android.

Instrumen angket yang akan digunakan dalam pengambilan data yang sebenarnya diujicobakan kepada kelompok lain dengan maksud untuk mengetahui tingkat validitas dan reliabilitas instrumen.

Pengolahan data pada penelitian ini dilakukan dengan mengolah data angket dengan menggunakan teknik statistik diskriptif kuantitatif yang selanjutnya dimaknai. Untuk mendiskripsikan data penelitian digunakan mean ideal dan standar deviasi ideal sebagai acuan kriteria. Data kuantitatif dalam sebaran skor diklarifikasikan dalam bentuk tabel distribusi untuk melihat kecenderungan masing-masing skor dengan cara menggunakan mean ideal (Mi) dan standar deviasi ideal (SDi) dari subyek penelitian. Dari harga-harga tersebut dapat dikategorikan dalam lima klasifikasi sebagai berikut:

\section{Tabel 1}

Rumus Menentukan Kelas Interval

\begin{tabular}{ll}
\hline \multicolumn{1}{c}{ Kelas Interval } & \multicolumn{1}{c}{ Kategori } \\
\hline$(\mathrm{Mi}+1,50 \mathrm{SDi})<\mathrm{X}$ & Sangat Baik \\
$(\mathrm{Mi}+0,50 \mathrm{SDi})<\mathrm{X} \leq(\mathrm{Mi}$ & Baik \\
$+1,50 \mathrm{SDi})$ & \\
$(\mathrm{Mi}-0,50 \mathrm{SDi})<\mathrm{X} \leq(\mathrm{Mi}$ & Cukup \\
$+0,50 \mathrm{SDi})$ & \\
$(\mathrm{Mi}-1,50 \mathrm{SDi})<\mathrm{X} \leq(\mathrm{Mi}$ & Kurang Baik
\end{tabular}




\begin{tabular}{ll}
\hline$-0,50$ SDi $)$ & \\
$X \leq(M-1,50$ SDi $)$ & Tidak Baik \\
\hline & $($ Azwar 2015)
\end{tabular}

\section{HASIL DAN PEMBAHASAN}

Data yang diperoleh dari angket yang telah disebar kepada 37 responden kemudian diperoleh hasil analisis data sebagai berikut:

\section{1) Pemahaman mahasiswa tentang} Mobile learning Berbasis Android

Pemahaman mahasiswa tentang sistem mobile learning berbasis android diukur melalui angket yang berisi 20 pernyataan menggunakan skala likert dengan skor 1 sampai 4 , sehingga dapat diketahui nilai-nilai parameter idealnya sebagai berikut:

Skor minimum ideal $=20 \times 1=20$

Skor maksimum ideal $=20 \times 4=80$

Nilai rata-rata ideal $(\mathrm{Mi})=(80+20) / 2=50$

Nilai standar deviasi ideal $($ SDi $)=(80-20) / 6$ $=10$

Untuk mengetahui kecenderungan skor variabel pemahaman mahasiswa terhadap mobile learning berbasis android didapatkan hasil kelas interval berikut.

\section{Tabel 2}

Kelas Interval

\begin{tabular}{cl}
\hline Kelas Interval & \multicolumn{1}{c}{ Kategori } \\
\hline$X>65$ & Sangat Paham \\
$55<X \leq 65$ & Paham \\
$45<X \leq 55$ & Cukup Paham \\
$35<X \leq 45$ & Kurang Paham \\
$X<35$ & Tidak Paham \\
\hline
\end{tabular}

Analisis pemahaman mahasiswa terhadap mobile learning berbasis android secara keseluruhan adalah sebagai berikut.

Tabel 3

Distribusi Frekuensi Pemahaman Mahasiswa Terhadap Mobile learning Berbasis Android

\begin{tabular}{clcc}
\hline Interval & Kategori & $\mathbf{F}$ & $\%$ \\
\hline $\mathrm{X}>65$ & $\begin{array}{l}\text { Sangat } \\
\text { Paham }\end{array}$ & 0 & $0 \%$ \\
$55<\mathrm{X} \leq$ & Paham & 27 & $72,97 \%$ \\
65 & & & \\
$45<\mathrm{X} \leq$ & Cukup & 10 & $27,03 \%$ \\
55 & Paham & & \\
$35<\mathrm{X} \leq$ & Kurang & 0 & $0 \%$ \\
45 & Paham & & \\
$\mathrm{X}<35$ & Tidak & 0 & $0 \%$ \\
& Paham & & $100 \%$ \\
\hline
\end{tabular}

Berdasarkan tabel di atas dapat disimpulkan bahwa Persepsi mahasiswa berkaitan dengan pemahaman terhadap mobile learning berada pada kategori baik dengan frekuensi 27 dan presentase $72,97 \%$. Selebihnya pada kategori cukup baik diperoleh frekuensi sebesar 10 dengan presentase $27,03 \%$, pada kategori sangat baik dan kurang baik diperoleh frekuensi masing-masing sebesar 0 dengan presentase $0 \%$.

\section{Manfaat Android dalam pembelajaran Mahasiswa \\ Persepsi mahasiswa terhadap} manfaat mobile learning berbasis android diukur melalui angket yang berisi 12 pernyataan menggunakan skala likert dengan skor 1 sampai 4 , sehingga dapat diketahui nilai-nilai parameter idealnya sebagai berikut: 
Skor minimum ideal $=12 \times 1=12$

Skor maksimum ideal $=12 \times 4=48$

Nilai rata-rata ideal $(\mathrm{Mi})=(48+12) / 2=30$

Nilai standar deviasi ideal $(\mathrm{SDi})=(48-$

$12) / 6=6$

Untuk mengetahui kecenderungan skor variabel persepsi mahasiswa mengenai manfaat mobile learning berbasis android didapatkan hasil kelas interval berikut.

Tabel 4

Kelas Interval

\begin{tabular}{cl}
$\begin{array}{c}\text { Kelas } \\
\text { Interval }\end{array}$ & \multicolumn{1}{c}{ Kategori } \\
\hline$X>39$ & $\begin{array}{l}\text { Sangat } \\
\text { Bermanfaat }\end{array}$ \\
$33<X \leq 39$ & Bermanfaaat \\
$27<X \leq 33$ & Cukup \\
& Bermanfaat \\
$21<X \leq$ & Kurang \\
27 & Bermanfaat \\
$X<21$ & Tidak Paham \\
\hline
\end{tabular}

Analisis persepsi mahasiswa mengenai manfaat mobile learning berbasis android adalah sebagai berikut.

Tabel 5

Distribusi Frekuensi Persepsi Mahasiswa Mengenai Manfaat Mobile learning Berbasis Android

\begin{tabular}{|c|c|c|c|}
\hline Interval & Kategori & $\mathbf{F}$ & $\%$ \\
\hline$X>39$ & $\begin{array}{l}\text { Sangat } \\
\text { Bermanfaat }\end{array}$ & 4 & 10,82 \\
\hline $\begin{array}{c}33<\mathrm{X} \leq \\
39\end{array}$ & Bermanfaaat & 28 & 75,67 \\
\hline $\begin{array}{c}27<X \leq \\
33\end{array}$ & $\begin{array}{l}\text { Cukup } \\
\text { Bermanfaat }\end{array}$ & 3 & 8,10 \\
\hline $\begin{array}{c}21<X \leq \\
27\end{array}$ & $\begin{array}{l}\text { Kurang } \\
\text { Bermanfaat }\end{array}$ & 2 & 5,40 \\
\hline$X<21$ & $\begin{array}{l}\text { Tidak } \\
\text { Paham }\end{array}$ & 0 & 0 \\
\hline & JMLAH & 37 & 100 \\
\hline
\end{tabular}

Berdasarkan tabel di atas dapat disimpulkan bahwa persepsi mahasiswa terhadap manfaat mobile learning berbasis android berada pada kategori bermanfaat dengan frekuensi 28 dan presentase $75,67 \%$. Selebihnya pada kategori cukup baik diperoleh frekuensi sebesar 3 dengan presentase $8,10 \%$, pada kategori sangat baik diperoleh frekuensi 4 dengan persentase $10,82 \%$ dan kurang baik diperoleh frekuensi sebesar 2 dengan presentase $5,40 \%$.

\section{Persepsi mahasiswa tentang kesiapan mahasiswa menggunakan mobile learning berbasis android}

Persepsi mahasiswa tentang kesiapan mahasiswa dalam menggunakan mobile learning berbasis android diukur melalui angket yang berisi 16 pernyataan menggunakan skala likert dengan skor 1 sampai 4, sehingga dapat diketahui nilainilai parameter idealnya sebagai berikut:

Skor minimum ideal $=16 \times 1=16$

Skor maksimum ideal $=16 \times 4=64$

Nilai rata-rata ideal $(\mathrm{Mi})=(64+16) / 2=40$

Nilai standar deviasi ideal $(\mathrm{SDi})=(64-16) / 6$ $=8$

Untuk mengetahui kecenderungan skor variabel persepsi mahasiswa tentang kesiapan mahasiswa dalam menggunakan mobile learning berbasis android didapatkan hasil kelas interval berikut.

Tabel 6

Kelas Interval

\begin{tabular}{cc}
\hline Kelas Interval & Kategori \\
\hline$X>52$ & Sangat Baik \\
$44<X \leq 52$ & Baik \\
$36<X \leq 38,5$ & Cukup Baik \\
\hline
\end{tabular}




\begin{tabular}{cc}
\hline $28<\mathrm{X} \leq 36$ & Kurang Baik \\
$\mathrm{X}<28$ & Tidak Baik \\
\hline
\end{tabular}

Analisis persepsi mahasiswa tentang kesiapan mahasiswa dalam menggunakan mobile learning berbasis android adalah sebagai berikut.

\section{Tabel 7}

Distribusi Frekuensi Persepsi Mahasiswa Tentang Kesiapan Mahasiswa Dalam Menggunakan Mobile learning Berbasis Android

\begin{tabular}{clcc}
\hline Interval & Kategori & $\mathbf{F}$ & $\%$ \\
$X>52$ & $\begin{array}{l}\text { Sangat } \\
\text { Baik }\end{array}$ & 4 & $10,82 \%$ \\
$44<X \leq 52$ & Baik & 30 & $81,08 \%$ \\
$36<X \leq$ & Cukup & 3 & $8,11 \%$ \\
38,5 & Baik & & \\
$28<X \leq$ & Kurang & 0 & $0 \%$ \\
36 & Baik & & \\
$X<28$ & Tidak Baik & 0 & $0 \%$ \\
\multicolumn{2}{c}{ JUMLAH } & 37 & $100 \%$ \\
\hline
\end{tabular}

Berdasarkan tabel di atas dapat disimpulkan bahwa persepsi mahasiswa tentang kesiapan mahasiswa dalam menggunakan mobile learning berbasis android berada pada kategori baik dengan frekuensi 30 dan presentase $81,08 \%$. Selebihnya pada kategori cukup baik diperoleh frekuensi sebesar 3 dengan presentase $8,11 \%$, pada kategori sangat baik diperoleh frekuensi 4 dengan persentase $10,82 \%$. Sedangkan untuk kategori kurang baik dan tidak baik dengan frekuensi 0 atau $0 \%$.

Temuan penelitian menunjukkan bahwa persepsi mahasiswa terhadap mobile learning berbasis android di Program Studi Teknologi Pendidikan adalah baik (positif) dilihat dari sisi sistem pemahaman, kebermanfaatan, dan kesiapan mahasiswa dalam pembelajaran. Mahasiswa telah baik memahami konsep dan manfaat mobile learning berbasis android. Mahasiswa juga telah memiliki fasilitas dan kesiapan yang baik dalam penggunaan mobile learning berbasis android.

Dari aspek pemahaman, mahasiswa memiliki pengetahuan yang baik dalam memahami mobile learning berbasis android. Mereka mengetahui bahwa mobile learning merupakan turunan dari e-learning dengan penggunaan media mobile yang berkaitan dengan smarthphone atau android.

Dari aspek manfaat, sebagian besar mahasiswa telah merasakan manfaat android membantu kegiatan pembelajaran mereka selama ini seperti memudahkan belajar, memberikan motivasi, dan membantu belajar. Hal ini mereka tuliskan pada tambahan kolom angket yang menyatakan bentuk penggunaan web browser dalam membantu referensi materi mata kuliah yang mereka pelajari.

Mobile learning sebagai urunan bagian dari e-learning pada hakikarnya memiliki manfaat yang hampir saya. E-learning membantu mahasiswa untuk mempelajari materi secara mandiri sebelum masuk kelas, dengan mempelajari materi yang disediakan melalui e-learning dapat meningkatkan motivasi mahasiswa dalam proses pembelajaran di dalam kelas. Pembelajaran dengan e-learning berbeda dengan pembelajaran secara konvensional, dimana dalam pembelajaran dengan e-learning guru tidak berperan sebagai sumber informasi utama yang menyalurkan informasi kepada siswa (Jayawardana, 2017).

Dari aspek kesiapan, mahasiswa menyatakan kesiapan mereka untuk menggunakan mobile learning berbasis android dalam pembelajaran yang mereka lakukan kedepannya. Hal ini ditunjang dari mayoritas mahasiswa menggunakan 
smarthphone android sebagai ponsel pribadi. Internet yang menjadi syarat utama dilaksanakannya pembelajaran ini menjadi catatan yang mereka ajukan untuk menunjang pembelajaran.

Temuan persepsi ini menjadi dasar bagi peneliti untuk penyelenggaraan kegiatan pembelajaraan khususnya pengembangan pembelajaran e-learning. Persepsi seseorang terhadap e-learning mempengaruhi kemauan dalam menggunakannya atau tidak, dan kemudahan seseorang dalam menggunakan teknologi (e-learning) akan memberikan pengaruh pada sikap pengguna (Aziz, Al Musadieq, \& Susilo, 2013).

\section{E. KESIMPULAN}

Sebanyak $72,97 \%$ mahasiswa memahami mobile learning berbasis andorid, $75,67 \%$ mengetahui manfaat mobile learning berbasis android, dan $81,08 \%$ menyatakan kesiapan dalam penggunaan mobile learning berbasis android.

Berdasarkan hasil temuan penelitian tersebut dapat disimpulkan bahwa persepsi mahasiswa Program Studi Teknologi Pendidikan FKIP Universitas Baturaja terhadap mobile learning berbasis android tergolong positif atau baik. Hal ini memperlihatkan bahwa mahasiswa memahami konsep utama dan manfaat mobile learning berbasis android, serta memiliki kesiapan untuk penggunaan mobile learning berbasis android.

Meskipun temuan penelitian menyatakan persepsi mahasiswa positif atau baik terhadap mobile learning berbasis android, namun sebagai catatan bahwa mahasiswa masih terkendala mengenai akses internet yang kadang terbatas dimiliki oleh mahasiswa.

Dengan demikian, dosen di Universitas Baturaja, khususnya Program Studi Teknologi Pendidikan yang akan mengembangkan keilmuaannya dapat menggunakan, memanfaatakan atau mengembangkan mobile learning berbasis android dalam pembelajaran. Hal ini juga dapat dijadikan variasi dan inovasi pembelajaran sehingga pembelajaran tidak monoton dan dapat memberikan semangat belajar mahasiswa, serta mampu membantu keterbatasan waktu dan tempat.

\section{DAFTAR PUSTAKA}

Aziz, A. L. (2013). Pengaruh Kemudahan Penggunaan Terhadap Kemanfaatan Pada Sikap Pengguna E-learning Survei Pada Mahasiswa Jurusan Administrasi Bisnis, Fakultas Ilmu Administrasi Universitas Brawijaya Malang Angkatan 2011. Jurnal Administrasi Bisnis, 6(2).

Azwar, S. (2015). Tes prestasi: Fungsi dan pengembangan pengukuran prestasi belajar. Yogyakarta: Pustaka Pelajar.

Belina, E., \& Batubara, F. R. (2013). Perancangan dan implementasi aplikasi e-learning versi mobile berbasis android. Singuda ensikom, 4(3), 76-81.

Chandrawati, S. R. (2010). Pemamfaatan E-learning dalam Pembelajaran. Jurnal Cakrawala Kependidikan, 8(2).

Chao, J. T., Parker, K. R., \& Fontana, A. (2011). Developing an interactive social media based learning environment. Issues in Informing Science and Information Technology, 8(2011), 323-334. 
Demidowich, A. P., Lu, K., Tamler, R., \& Bloomgarden, Z. (2012). An evaluation of diabetes self-management applications for Android smartphones. Journal of telemedicine and telecare, 18(4), 235-238.

Higgins, M., \& Shudong, W. (2012). Limitations of Mobile Phone Learning. The Jalt CALL Journal, 2(1), 1832-4215.

Jayawardana, H. B. A. (2017). Paradigma Pembelajaran Biologi di Era Digital. Jurnal Bioedukatika, 5(1), 12-17.

Kustandi, C., \& Sutjipto, B. (2011). Media pembelajaran manual dan digital. Bogor: Ghalia Indonesia.

Listyorini, T. (2013). Perancangan mobile learning mata kuliah sistem operasi berbasis android. Simetris: Jurnal Teknik Mesin, Elektro dan IImu Komputer, 3(1), 25-30.

Matlubah, H., Anekawati, A., \& Ngadi. (2016). Aplikasi Mobile learning Berbasis Smartphone. Jurnal Lensa, 85-98.

Michael, A. (2013). Michael Allen's Guide to E-learning. Canada: John Wiley \& Sons.

Nursalam, N., \& Efendi, F. (2008). Pendidikan Dalam Keperawatan Education in Nursing.

Rosenberg, M. J. (2001). E-learning: Building successful online learning in your organization. McGrow Hill, New York, NY, USA.

Prabowo, I. J. K. G., Setiawan, A., \& Prakoso, S. T. (2014). Pengembangan Sistem Mobile Journal Berbasis Android Untuk Referensi Belajar Mahasiswa Di Lingkungan Fakultas Ekonomi UNY. Program Kreativitas Mahasiswa-Karsa Cipta.

Saifuddin, M. F. (2018). E-learning dalam Persepsi Mahasiswa. Jurnal VARIDIKA, 29(2), 102109.

Sulisworo, D., Jauhari, I., \& Firdausy, K. (2014). Pengembangan Sistem Manajemen Pembelajaran Kooperatif Secara Mobile Berbasis Sistem Operasi Android. Indonesian Journal of Curriculum and Educational Technology Studies,3 (1), 56-63.

Thohari, A. N. A., Satoto, K. I., \& Martono, K. T. (2013). Pembuatan Aplikasi Mobile learning sebagai Sarana Pembelajaran di Lingkungan Universitas Diponegoro. Jurnal Teknologi dan Sistem Komputer, 1(2), 56-65.

www.gs.statcounter.com 